\title{
The Metabolism of Circulating Maltose in Man
}

\author{
Sister John M. Young and Elliot Weser \\ From the Department of Physiology and Medicine, The University of Texas \\ Medical School, San Antonio, Texas 78229
}

A в STRACT The utilization of circulating maltose was compared to that of glucose in six normal fasting subjects after intravenous injection of $25 \mathrm{~g}$ of either sugar. Blood samples were obtained over a $2 \mathrm{hr}$ period and were assayed for free fatty acids (FFA), insulin, glucose, and total reducing substances. Urine was collected for $2 \mathrm{hr}$ after maltose administration and assayed enzymatically for glucose and maltose. Blood glucose concentrations did not increase after maltose infusion, although a significant rise in total reducing substances was noted, indicating the presence of this disaccharide in the blood. Less than $3 \%$ of the administered maltose was excreted in the urine either as maltose or glucose. Initially, there was a fourfold increase in serum insulin concentration after glucose and a threefold increase after maltose infusion. Therefore, serum insulin concentrations gradually declined in a similar manner for both sugars. The plasma FFA at $15 \mathrm{~min}$ decreased $371 \mathrm{uEq} /$ liter after glucose and $338 \mathrm{uEq} /$ liter after maltose infusion.

In other studies, $10 \mathrm{~g}$ maltose containing $5 \mu \mathrm{Ci}$ maltose-U- ${ }^{14} \mathrm{C}$ were injected into five human subjects and expired $\mathrm{CO}_{2}$ collected for $6 \mathrm{hr}$. Maximal ${ }^{14} \mathrm{CO}_{2}$ specific activity was noted at $170 \mathrm{~min}$ and a mean of $61.1 \%$ of the injected radioactivity was recovered as ${ }^{14} \mathrm{CO}_{2}$. Less than $8 \%$ of the injected ${ }^{14} \mathrm{C}$ was excreted in the urine.

These results indicate that maltose administered intravenously has similar metabolic effects when compared to glucose, and may be efficiently utilized as a carbohydrate substrate. The oxidation of intravenously administered maltose- $\mathrm{U}_{-}{ }^{14} \mathrm{C}$ to ${ }^{14} \mathrm{CO}_{2}$ demonstrates that circulating maltose is readily metabolized. A solution of maltose could provide twice the mass of sugar (and of calories) per milliliter as an equimolar solution of glucose. Parenterally administered maltose may be of clinical value and should be further studied.

This work was presented in part at the meeting of the Southern Society for Clinical Investigation, New Orleans, La., 31 January 1970.

Received for publication 17 September 1970 and in revised form 30 November 1970.

\section{INTRODUCTION}

In the rat, parenterally administered maltose is oxidized to $\mathrm{CO}_{2}$ equally as well as glucose and is not excreted in the urine (1-3). On the other hand, lactose and sucrose are poorly oxidized and are mainly excreted in the urine $(1,4,5)$. It has been shown that the incorporation of intravenously injected maltose and glucose into rat epididymal lipids is similar (3). Furthermore, the rate of oxidation of maltose to $\mathrm{CO}_{2}$, as well as the incorporation of maltose into epididymal lipids, is enhanced when insulin is simultaneously administered with the disaccharide (3).

After lactose or sucrose infusion in man, these disaccharides are excreted extensively in the urine $(1,6,7)$. After maltose infusion, only small quantities of the sugar appear in the urine, suggesting that this disaccharide is metabolized (1). In the present study, the metabolism of circulating maltose is compared with that of glucose.

\section{METHODS}

Maltose solutions were prepared by dissolving $50 \mathrm{~g}$ maltose ${ }^{1}$ in $100 \mathrm{ml}$ sterile, distilled water, and autoclaving the solutions at $250^{\circ} \mathrm{C}$ for $15 \mathrm{~min}$. Samples were cultured on fluid Thioglycollate medium ${ }^{2}$ for $48 \mathrm{hr}$ to rule out bacterial contamination. Before and after autoclaving, portions of the maltose solutions were subjected to descending paper chromatography using ethyl acetate, pyridine, and water (2:1:2 $\mathrm{v} / \mathrm{v}$ ) as the solvent system. Chromatograms were developed using the silver dip method of Anet and Reynolds (8). The solutions contained maltose, with insignificant amounts of glucose at a concentration no greater than $1.3 \%$ when measured by the glucose oxidase method. ${ }^{3}$ The $50 \%$ USP dextrose injection solutions were commercial products."

After an overnight fast, six healthy, normal-weight human subjects, two males and four females ranging in age from 26 to $43 \mathrm{yr}$ were injected intravenously with $25 \mathrm{~g}$ of either glucose or maltose in $50 \mathrm{ml}$ water prepared as described above. All infusions were given over a $5 \mathrm{~min}$ period.

\footnotetext{
${ }^{1}$ Pfanstiehl Labs. Inc., Waukegan, I11.

${ }^{2}$ BBL, Division of Bio Quest, Cockeysville, Md.

${ }^{3}$ Glycostat enzymatic determination of glucose. Worthington Biochemical Corp., Freehold, N. J.

${ }^{\star} \mathrm{McGaw}$ Laboratories, Inc., Glendale, Calif.
} 
TABLE I

Metabolic Response to the. Intravenous Administration of Maltose and Glucose

\begin{tabular}{|c|c|c|c|c|c|c|c|}
\hline & \multirow{2}{*}{$\begin{array}{l}\text { Sugar } \\
(25 \mathrm{~g})\end{array}$} & \multicolumn{6}{|c|}{ Minutes after infusion } \\
\hline & & 0 & 15 & 30 & 60 & 90 & 120 \\
\hline $\begin{array}{l}\text { Serum glucose, } \\
\quad m g / 100 \mathrm{ml}\end{array}$ & $\begin{array}{l}\text { Glucose } \\
\text { Maltose }\end{array}$ & $\begin{array}{c}78.6 \pm 10.5^{*} \\
83.5 \pm 8.6 \\
\text { NS } \ddagger\end{array}$ & $\begin{array}{c}221.8 \pm 73.5 \\
95.9 \pm 9.7 \\
P<0.01\end{array}$ & $\begin{array}{c}141.2 \pm 21.8 \\
97.2 \pm 14.5 \\
P<0.01\end{array}$ & $\begin{array}{c}85.9 \pm 23.6 \\
97.7 \pm 7.7 \\
\text { NS }\end{array}$ & $\begin{array}{l}75.1 \pm 13.0 \\
95.4 \pm 12.7 \\
P<0.05\end{array}$ & $\begin{array}{c}76.2 \pm 13.1 \\
90.7 \pm 7.9 \\
\mathrm{NS}\end{array}$ \\
\hline $\begin{array}{l}\text { Total serum rec } \\
\text { ing substances } \\
m g / 100 m l\end{array}$ & Maltose & $93.0 \pm 13.1$ & $202.9 \pm 29.6$ & $162.9 \pm 28.8$ & $137.9 \pm 28.7$ & $119.3 \pm 28.1$ & $103.1 \pm 28.7$ \\
\hline $\begin{array}{l}\text { Serum insulin, } \\
\quad \mu U / m l\end{array}$ & $\begin{array}{l}\text { Glucose } \\
\text { Maltose }\end{array}$ & $\begin{array}{c}12.0 \pm 6.0 \\
11.6 \pm 4.8 \\
\mathrm{NS}\end{array}$ & $\begin{array}{c}50.0 \pm 9.0 \\
34.2 \pm 9.8 \\
P<0.05\end{array}$ & $\begin{array}{l}38.6 \pm 7.9 \\
30.1 \pm 10.3 \\
\quad \text { NS }\end{array}$ & $\begin{array}{c}30.9 \pm 6.4 \\
26.6 \pm 7.2 \\
\mathrm{NS}\end{array}$ & $\begin{array}{c}18.3 \pm 7.3 \\
26.5 \pm 8.3 \\
\text { NS }\end{array}$ & $\begin{array}{c}15.1 \pm 10.3 \\
13.4 \pm 6.7 \\
\text { NS }\end{array}$ \\
\hline $\begin{array}{c}\text { Plasma FFA, } \\
\mu E q / \text { liter }\end{array}$ & $\begin{array}{l}\text { Glucose } \\
\text { Maltose }\end{array}$ & $\begin{array}{c}635.7 \pm 286.1 \\
657.8 \pm 217.9 \\
\text { NS }\end{array}$ & $\begin{array}{c}265.1 \pm 94.8 \\
319.9 \pm 43.4 \\
\text { NS }\end{array}$ & $\begin{array}{c}201.4 \pm 54.8 \\
312.4 \pm 40.0 \\
P<0.01\end{array}$ & $\begin{array}{c}168.5 \pm 46.5 \\
313.4 \pm 45.1 \\
P<0.01\end{array}$ & $\begin{array}{c}195.6 \pm 56.1 \\
315.8 \pm 60.7 \\
P<0.01\end{array}$ & $\begin{array}{c}251.7 \pm 63.9 \\
324.6 \pm 48.1 \\
P<0.05\end{array}$ \\
\hline
\end{tabular}

* Mean 土SEM for six subjects.

‡ Statistical comparisons are all between the value observed after glucose as compared to after maltose for the given time.

Venous blood samples were obtained at fasting and at 15 , $30,60,90$, and $120 \mathrm{~min}$ after sugar infusion. Blood plasma samples were assayed for free fatty acids (FFA) (9), and serum insulin was determined by charcoal immunoassay analysis (10). True glucose ${ }^{3}$ was measured for all samples, while only samples obtained after maltose infusion were assayed for total reducing substances (11). Blood maltose concentrations were calculated as the difference between total serum reducing substances and serum glucose concentrations. Urine was collected for $2 \mathrm{hr}$ after maltose infusion and was desalted with Amberlite ion exchange resin ${ }^{5}$ IR-120 and IR-45 according to the method of Saloman and Johnson (12). The desalted urine was assayed enzymatically for both glucose ${ }^{3}$ and maltose (13).

In other experiments, $10 \mathrm{~g}$ of maltose containing $5 \mu \mathrm{Ci}$ maltose-U- ${ }^{14} \mathrm{C}^{6}$ dissolved in $50 \mathrm{ml}$ water were infused into an antecubital vein of five healthy, fasting, female subjects. All maltose solutions were cultured and chromatographed as described. Immediately after injection, the expired breath of the subjects was collected for $10 \mathrm{~min}$ at 20 -min intervals for $2 \mathrm{hr}$, and subsequently at 30-min intervals for $4 \mathrm{hr}$. A 200 -liter Darex meteorological balloon ${ }^{7}$ arranged in a Donald-Christie box (14) was used to collect the expired air. This apparatus was attached to a Tissot spirometer for measurement of total volume of expired air for each collection interval. Duplicate portions were then assayed for expired $\mathrm{CO}_{2}$ and ${ }^{14} \mathrm{CO}_{2}$ according to the method of Fredrickson and Ono (15). Radioactivity of $\mathrm{CO}_{2}$ was measured in a Packard liquid scintillation spectrometer and specific activity of ${ }^{14} \mathrm{CO}_{2}$ was calculated as the fraction of injected ${ }^{14} \mathrm{C}$ expired per millimole $\mathrm{CO}_{2}$. Urine was collected over the $6 \mathrm{hr}$ period,

${ }^{5}$ Mallinckrodt Chemical Works, St. Louis, Mo.

${ }^{B}$ Calbiochem, Los Angeles, Calif.

${ }^{7}$ Dewey and Almy Chemical Division, W. R. Grace and Company, 7 Hanover Square, New York. and the total radioactivity excreted was calculated as percentage of injected dose. Venous blood samples were withdrawn at 20,40, and $60 \mathrm{~min}$ after injection. Urine and serum samples were assayed for glucose $^{3}$ and for total reducing substances (11). The radioactivity of the serum was too low to be detected in the sugar separated by paper chromatography. Therefore, in one male subjert, $10 \mathrm{~g}$ maltose containing $55 \mu \mathrm{Ci}$ maltose- $\mathrm{U}_{-}^{14} \mathrm{C}$ was injected intravenously and blood collected at $0,15,30,45$, and $60 \mathrm{~min}$ after injection. Portions of deproteinized and desalted serum were subjected to descending paper chromatography as described. Maltose and glucose spots were identified by the use of reference standards and selectively cut out and placed in counting vials containing phosphor as described (15). Radioactivity was determined in a liquid scintillation spectrometer. The concentration of glucose and total reducing substances was also determined in portions of the serum.

Analysis of variance, standard errors, and Student's $t$ tests were calculated according to standard methods (16).

\section{RESULTS}

The concentration of serum glucose, insulin, total reducing substances, and FFA following intravenous administration of $25 \mathrm{~g}$ maltose and glucose are summarized in Table I. After glucose infusion the serum glucose increased from $78.6 \pm 10.5$ to $221.8 \pm 73.5 \mathrm{mg} / 100 \mathrm{ml} \mathrm{se}-$ rum at $15 \mathrm{~min}$, returning to near fasting concentrations by $60 \mathrm{~min}$. In contrast, after maltose infusion, there was no significant increase in serum glucose during the entire $2 \mathrm{hr}$ interval. Despite the insignificant change in serum glucose after maltose infusion, total reducing substances in the blood increased from $93 \pm 13.1$ to 202.9 


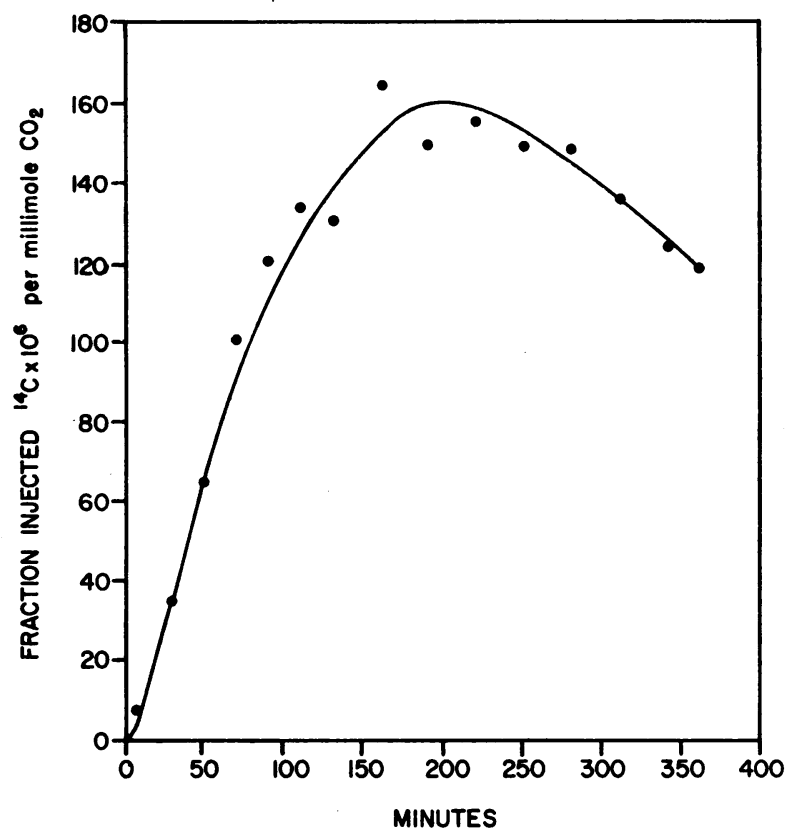

FIgURE 1 The fraction of injected ${ }^{14} \mathrm{C}$ recovered as expired ${ }^{14} \mathrm{CO}_{2}$ per millimole $\mathrm{CO}_{2}$ over a $6 \mathrm{hr}$ period after the intravenous administration of $10 \mathrm{~g}$ of ${ }^{14} \mathrm{C}$-labeled maltose. Points are mean values for five subjects.

$\pm 29.6 \mathrm{mg} / 100 \mathrm{ml}$ serum. The "estimated" serum maltose concentrations at $15,30,60$, and $90 \mathrm{~min}$ were $106 \pm 26.3$, $65.5 \pm 20.5,40.2 \pm 22.5$, and $23.9 \pm 19.6 \mathrm{mg}$ per $100 \mathrm{ml}$ serum.

Very little of the administered maltose was recovered in the urine during a $2 \mathrm{hr}$ period. Less than $0.01 \%$ of the infused maltose was recovered as maltose, while $2.2 \%$ was excreted as glucose.

The serum insulin concentration increased from 11.6 \pm 4.8 to $34.2 \pm 9.8 \mu \mathrm{U} / \mathrm{ml}$ after maltose infusion, representing a 3-fold rise (Table I). Following glucose infusion, there was a 4-fold increase in serum insulin from

TABLE II

Recovery of ${ }^{14} \mathrm{C}$ after the Intravenous Administration of $10 \mathrm{~g}$ of ${ }^{14} \mathrm{C}$-Labeled Maltose

\begin{tabular}{ccc}
\hline Subjects & ${ }^{14} \mathrm{CO}_{2}$ & Urinary ${ }^{14 \mathrm{C}}$ \\
\hline & $\%$ dose & \% dose \\
1 & 72.6 & 8.7 \\
2 & 48.4 & 10.8 \\
3 & 79.0 & 3.0 \\
4 & 30.1 & 1.9 \\
5 & 75.5 & 12.8 \\
Mean & 61.1 & 7.4 \\
SEM & 9.4 & 2.1 \\
\hline
\end{tabular}

$12.0 \pm 6.0$ to $50.0 \pm 9.0 \mu \mathrm{U} / \mathrm{ml}$ serum. Subsequent concentrations of serum insulin were similar for both sugars.

A precipitous drop in plasma FFA was noted after infusion of both maltose and glucose (Table I). The initial response of plasma FFA was essentially similar after the infusion of either carbohydrate. It was noted, however, that after this initial response, glucose produced a statistically significant reduction in FFA when compared to the reduction after maltose infusion (Table I).

When $10 \mathrm{~g}$ maltose containing $5 \mu \mathrm{Ci}$ maltose $-\mathrm{U}-{ }^{14} \mathrm{C}$ was given intravenously to five women (23 to 47 years), this disaccharide was readily metabolized to $\mathrm{CO}_{2}$. Specific activity of ${ }^{14} \mathrm{CO}_{2}$, expressed as the fraction of ${ }^{14} \mathrm{C}$ injected per millimole $\mathrm{CO}_{2}$, is shown in Fig. 1. Within the first $15 \mathrm{~min}$, radioactivity appeared in the expired air and maximal production of ${ }^{14} \mathrm{CO}_{2}$ was observed $170 \mathrm{~min}$ after injection. The amount of ${ }^{14} \mathrm{CO}_{2}$ expired during the $6 \mathrm{hr}$ varied widely among individuals with a mean and SEM of $61.6 \pm 9.4 \%$ of the radioactivity administered (Table II). Less than $8 \%$ of the administered radioisotope was recovered in the urine either as maltose or as glucose.

There was no significant change in serum glucose concentration at 20,40, and $60 \mathrm{~min}$ after intravenous infusion of $10 \mathrm{~g}$ of radioactive maltose. The mean values were $87.1 \pm 1.4,85.2 \pm 0.1$, and $83.2 \pm 0.9 \mathrm{mg} / 100 \mathrm{ml}$ serum. However, the total reducing substances of serum at 20,40 , and $60 \mathrm{~min}$ were $164.2 \pm 15.3,137.0 \pm 15.1$, and $117.6 \pm 7.1 \mathrm{mg} / 100 \mathrm{ml}$; therefore, the estimated serum maltose concentrations were $77.1 \pm 28.8,51.7 \pm 15.2$, and $34.1 \pm 7.7 \mathrm{mg} / 100 \mathrm{ml}$ respectively.

The specific activity (counts/minute per milligram) of serum glucose and maltose after intravenous administration of $55 \mu \mathrm{Ci}$ maltose $-\mathrm{U}-{ }^{14} \mathrm{C}$ in one subject is shown in Table III. Although there was no change in serum glucose concentration, the specific activity of glucose slowly increased during the $60 \mathrm{~min}$ period. On the other hand, the specific activity of the injected maltose remained relatively constant.

\section{TABLE III}

Specific Activity of Serum Glucose and Maltose after Intravenous Administration of $10 \mathrm{~g}$ Maltose- $U{ }^{14} \mathrm{C}^{*}$

\begin{tabular}{cccccc}
\hline & & & \multicolumn{2}{c}{ Specific activity } \\
\cline { 4 - 5 } \cline { 4 - 5 } Minutes & $\begin{array}{c}\text { Serum } \\
\text { glucose }\end{array}$ & $\begin{array}{c}\text { Estimated } \\
\text { maltose }\end{array}$ & Glucose & Maltose \\
\hline & $\begin{array}{c}m g / 100 \\
m l\end{array}$ & $\begin{array}{c}m g / 100 \\
m l\end{array}$ & \multicolumn{2}{c}{$c p m / m g$} \\
0 & 87 & 0 & 0 & 0 \\
15 & 92 & 61 & 209 & 5773 \\
30 & 90 & 50 & 487 & 6153 \\
45 & 90 & 34 & 878 & 5933 \\
60 & 94 & 31 & 1000 & 6975 \\
\end{tabular}

* 55 uCi Maltose-U-14C. 


\section{DISCUSSION}

The results of this study indicate that the utilization of circulating maltose elicits similar metabolic effects as glucose. The change in serum maltose after infusion was not accompanied by a significant elevation of glucose, suggesting that extracellular hydrolysis of maltose to glucose is minimal. Since human serum contains almost no maltose activity $(1,17)$, it is conceivable that maltose enters tissue cells intact and is subsequently metabolized. In this regard, maltose, rather than glucose, has been shown to be preferentially transported and metabolized by a variety of lower organisms (18-25). Selective utilization of maltose by growing cultures, cell suspensions and cell-free extracts of Neisseria meningitidis (19-21) has been reported. Maltose disappeared from the supernatant fluid when Micrococcus freudenreichii were incubated in maltose solutions (18), and chromatography performed on the supernatant fluid revealed no evidence of hydrolysis of maltose to glucose. Similarly, other organisms have been shown to transport and concentrate maltose intracellularly indicating a selective process by which maltose may enter cells $(18,22,24$, 25).

It has been well established that plasma FFA are elevated in fasting subjects, and rapidly decrease when carbohydrate becomes available for metabolism (26-28). While the FFA represent a minute amount of total plasma lipid, they have an exceptionally rapid turnover rate (29-32), and consequently may provide more calories than glucose (32). Thus, numerous studies show that FFA oxidation plays an important role in glucose homeostasis, and that glucose metabolism is rapidly modified by changes in the utilization of FFA (33-35). In the present study, the initial decrease in plasma FFA was essentially similar when $25 \mathrm{~g}$ of either maltose or glucose were given intravenously. Within the first 15 min, the plasma FFA decreased more than $51 \%$ when maltose was administered, and more than $58 \%$ when glucose was given. $2 \mathrm{hr}$ after glucose infusion however, plasma FFA began to rise toward fasting levels more rapidly than after maltose infusion. These results indicate that maltose is a readily available carbohydrate substrate, and that as this sugar is metabolized, the circulating plasma FFA decreases.

Numerous investigators have confirmed an insulinogenic response to a glycemic stimulus in animals (36, $37)$ and in man (38-41). In a recent study, intravenous administration of the metabolizable sugars (mannose and glucose) stimulated insulin secretion, while the nonutilizable sugars (galactose and 2-deoxy-D-glucose) did not (39). In our study, intravenous administration of maltose clearly stimulated a significant rise in serum insulin. It was also evident that increasing concentrations of circulating maltose stimulated insulin release even though this disaccharide was not hydrolyzed to glucose in the blood. Although the slight rise in serum glucose concentration after maltose infusion was not significant, the possible physiological importance of this concentration change should be considered. Several investigators have reported a direct relationship between rise in serum glucose concentration and increased serum insulin levels $(37,42,43)$. In vitro studies $(42)$, as well as in vivo studies in dogs (37) and in man (44-46), indicate that insulin secretion following intravenous administration of glucose is minimal as long as blood glucose concentrations remain below $100 \mathrm{mg}$ of glucose/100 $\mathrm{ml}$. In the present study, serum glucose concentrations following maltose infusion never surpassed $97 \mathrm{mg} / 100 \mathrm{ml}$ over the $2 \mathrm{hr}$ interval. There was no significant coefficient of correlation between serum glucose concentration and serum insulin concentration at any time interval. Coefficient of correlation between the per cent rise in serum glucose and the per cent rise in serum insulin from fasting to the $15 \mathrm{~min}$ interval was also not significant. The mechanism(s) controlling the secretion and synthesis of insulin have yet to be established (47). Control of basal insulin secretion from the beta cells does not appear to be wholly dependent upon the concentration of circulating blood glucose (49). Recent investigators have pointed out that intracellular metabolic events, such as the availability of cyclic adenylate (49-51), and the phosphorylation of glucose $(52,53)$ may indeed be the factors which stimulate the secretion of insulin. Data from the present study demonstrate that maltose is readily available as a metabolic substrate. Therefore, maltose may provide the required metabolite(s) necessary to initiate insulin secretion.

Current evidence indicates that insulin plays a major role in lowering blood concentrations of glucose, not only by increasing the rate of glucose removal, but also by decreasing the rate of glucose entry into the blood (54-56). It is possible that insulin may also enhance the entry of maltose into cells.

The specific activity of expired ${ }^{14} \mathrm{CO}_{2}$ during the $6 \mathrm{hr}$ period after intravenous administration of ${ }^{14} \mathrm{C}$-labeled maltose indicates the rapid and efficient metabolism of this disaccharide. The maximal specific activity at 170 min after infusion occurred later than that reported for ${ }^{14} \mathrm{C}$-labeled glucose by other investigators $(57-60)$. Comparison of maximal specific activity time for the oxidation of maltose-1-14 $\mathrm{C}$ and glucose-1- $-{ }^{14} \mathrm{C}$ to ${ }^{14} \mathrm{CO}_{2}$ in the rat has also been shown to be somewhat slower when maltose is the substrate (3). This difference may be explained by the time required for maltose to be hydrolyzed to glucose by tissue cells before oxidation to $\mathrm{CO}_{2}$.

The fraction of injected glucose- $\mathrm{U}^{14} \mathrm{C}$ recovered in human subjects as ${ }^{14} \mathrm{CO}_{2}$ over a $5 \mathrm{hr}$ period has been reported to range from 28.7 to $45.7 \%$ (57). The percentage 
recovery of injected maltose $-\mathrm{U}_{-}{ }^{14} \mathrm{C}$ for a $6 \mathrm{hr}$ period found in the present study ranged from 30.1 to $79.0 \%$ (Table II). Even correcting for differences in sample times, these values are higher than those reported for glucose (57). In a previous study similar results were noted in the rat (3). Comparison of the percentage recovery of intravenously administered glucose and maltose as expired $\mathrm{CO}_{2}$ suggests that the pathway by which maltose is metabolized favors oxidation to $\mathrm{CO}_{2}$.

It is of interest that the specific activity of serum glucose slowly increased after injection of maltose- $U_{-}{ }^{14} \mathrm{C}$ (Table III). Although this may result from some minimal intravascular hydrolysis of maltose to glucose, it more likely represent reentry of labeled glucose from tissue sources (59-61).

The ability of human subjects to metabolize circulating maltose suggests that this disaccharide may be useful as a source of calories for parenteral alimentation. Since glucose is used as the carbohydrate in many solutions prepared for hyperalimentation $(62,63)$, its replacement with maltose should be considered. In equimolar solutions, maltose should provide twice as many calories per unit volume as glucose. Further studies in man using maltose infusions are necessary to determine its clinical efficacy.

\section{ACKNOWLEDGMENTS}

We express gratitude to Dr. Frank Lecocq for determination of serum insulin. The technical assistance of Mary Hernandez, Marshall Pena, Molly Acosta, Sarah Hill, Dona Cutherell, and Bob San Martin is gratefully acknowledged.

This research was supported by Grant AM 12484 of the National Institute of Arthritis and Metabolic Diseases.

\section{REFERENCES}

1. Weser, E., and M. H. Sleisenger. 1967. Metabolism of circulating disaccharides in man and the rat. J. Clin. Invest. 46: 499 .

2. Dahlqvist, A., and D. L. Thomson. 1963. The digestion and absorption of maltose and trehalose by the intact rat. Acta Physiol. Scand. 59: 111.

3. Young, J. M., and E. Weser. 1970. Effect of insulin on the metabolism of circulating maltose. Endocrinology. 86: 426 .

4. Dahlqvist, A., and D. L. Thomson. 1964. The digestion and absorption of lactose by the intact rat. Acta Physiol. Scand. 61: 20 .

5. Dahlqvist, A., and D. L. Thomson. 1963. The digestion and absorption of sucrose by the intact rat. J. Physiol. (London). 167: 193.

6. Deane, N., G. E. Schreiner, and J. S. Robertson. 1951. The velocity of distribution of sucrose between plasma and interstitial fluid, with reference to the use of sucrose for the measurement of extraceilular fluid in man. $J$. Clin. Invest. 30: 1463.

7. Deane, N., and H. W. Smith. 1955. Fate of inulin and sucrose in normal subjects as determined by urine reinfusion technique. J. Clin. Invest. 34: 681 .
8. Anet, E. F. L. J., and T. M. Reynolds. 1954. Isolation of mucic acid from fruits. Nature (Paris). 174: 930.

9. Trout, D. L., E. H. Estes, Jr., and S. J. Friedberg. 1960. Titration of free fatty acids of plasma: a study of current methods and a new modification. J. Lipid Res. 1: 199.

10. Herbert, V., K.-S. Lau, C. W. Gottlieb, and S. J. Bleicher. 1965. Coated charcoal immunoassay of insulin. J. Clin. Endocrinol. 25: 1375.

11. Nelson, N. 1944. A photometric adaptation of the Somogyi method for the determination of glucose. $J$. Biol. Chem. 153: 375.

12. Salomon, L. L., and J. E. Johnson. 1959. Enzymatic microdetermination of glucose in blood and urine. Anal. Chem. 31: 453 .

13. Hestrin, S., D. S. Feingold, and M. Schramm. 1955. Hexoside hydrolases. Methods in Enzymol. 1: 231.

14. Donald, K. W., and R. V. Christie. 1949. A new method of clinical spirometry. Clin. Sci. 8: 21 .

15. Fredrickson, D. S., and K. Ono. 1958. An improved technique for assay of ${ }^{14} \mathrm{CO}_{2}$ in expired air using the liquid scintillation counter. J. Lab. Clin. Med. 51: 147.

16. Steel, R. G. H., and J. H. Torrie. 1960. In Principles and Procedures of Statistics with Special Reference to Biological Sciences. McGraw Hill Book Company, New York.

17. Van Handel, E. 1968. Trehalase and maltase in the serum of vertebrates. Comp. Biochem. Physiol. 26: 561.

18. Williams, P. J. leB., and I. J. McDonald. 1966. Permeability of micrococcal cell to maltose and some related sugars. Can. J. Microbiol. 12: 1213.

19. Fitting, C., and H. W. Scherp. 1951. Observations on a strain of Neisseria meningitidis in the presence of glucose and maltose. I. Growth studies. J. Bacteriol. 61: 203.

20. Fitting, C., and H. W. Scherp. 1952. Observations on a strain of Neisseria meningitidis in the presence of glucose and maltose. II. Studies with washed cells. $J$. Bacteriol. 63. 545.

21. Fitting, C., and H. W. Scherp. 1952. Observations on a strain of Neisseria meningitidis in the presence of glucose and maltose. J. Bacteriol. 64: 287.

22. Coleman, G. S. 1969. The metabolism of starch, maltose, glucose and some other sugars by the rumen ciliate $E n$ todinium caudatum. J. Gen. Microbiol. 57: 303.

23. Doudoroff, M., W. Z. Hassid, E. W. Putman and A. L. Potter. 1949. Direct utilization of maltose by Escherichia coli. J. Biol. Chem. 179: 921.

24. Wiesmeyer, H., and M. Cohn. 1960. The characterization of the pathway of maltose utilization by Escherichia coli. III. A description of the concentrating mechanism. Biochim. Biophys. Acta. 39: 440 .

25. Harris, G., and C. C. Thompson. 1961. The uptake of nutrients by yeast. III. The maltose permease of a brewing yeast. Biochim. Biophys. Acta 52: 176.

26. Fredrickson, D. S., and R. S. Gordon. 1958. Transport of fatty acids. Physiol. Rev. 38: 585 .

27. Gordon, R. S., and A. Cherkes. 1956. Unesterified fatty acid in human blood plasma. J. Clin. Invest. 35: 206.

28. Dole, V. P. 1956. A relation between non-esterified fatty acids in plasma and the metabolism of glucose. J. Clin. Invest. 35: 150.

29. Dole, V. P., and M. A. Rizack. 1961. On the turnover of long-chain fatty acids in plasma. J. Lipid Res. 2: 90.

30. Fredrickson, D. S., and R. S. Gordon, Jr. 1958. The metabolism of albumin-bound ${ }^{14} \mathrm{C}$-labeled unesterified fatty acids in normal human subjects. J. Clin. Invest. 37: 1504. 
31. Laurell, S. 1957. Turnover rate of unesterified fatty acids in human plasma. Acta Physiol. Scand. 41: 158.

32. Carlson, L. A., J. Boberg, and B. Högstedt. 1965. Some physiological and clinical implications of lipid mobilization from adipose tissue. In Handbook of Physiology. Section 5: Adipose Tissue. A. E. Renold, and G. F. Cahill, Jr., editors. The Williams \& Wilkins Co., Baltimore, Md. 625.

33. Dole, V. P. 1958. The significance of nonesterified fatty acids in plasma. Arch. Intern. Med. 101: 1005.

34. Randle, P. J. 1964. The interrelationships of hormones, fatty acids and glucose in the provision of energy. Postgrad. Med. J. 40: 457.

35. Ruderman, N. B., C. J. Toews, and E. Shafrir. 1969. The role of free fatty acids in glucose homeostasis. Arch. Intern. Med. 123: 299.

36. Anderson, E., and J. A. Long. 1947. The effect of hyperglycemia on insulin secretion as determined with the isolated rat pancreas in a perfusion apparatus. Endocrinology. 40: 92 .

37. Metz, R. 1958. The effect of the blood glucose on insulin secretion. J. Lab. Clin. Med. 52: 929.

38. Seltzer, H. S., and W. L. Smith. 1959. Plasma insulin activity after glucose: an index of insulogenic reserve in normal and diabetic man. Diabetes. 8: 417.

39. Karam, J. H., S. G. Grasso, L. C. Weigienka, G. M. Grodsky, and P. H. Forsham. 1966. Effect of selected hexoses, of epinephrine and of glucagon on insulin secretion in man. Diabetes. 15: 571.

40. Perley, M., and D. M. Kipnis. 1966. Plasma insulin responses to glucose and tolbutamide of normal weight and obese diabetic and nondiabetic subjects. Diabetes. 15: 867.

41. Seltzer, H. S., E. W. Allen, A. L. Herron, Jr., and M. T. Brennan. 1967. Insulin secretion in response to glycemic stimulus: relation of delayed initial release to carbohydrate intolerance in mild diabetes mellitus. $J$. Clin. Invest. 46: 323.

42. Malaisse, W., F. Malaisse-Lagae, and P. H. Wright. 1967. A new method for the measurement in vitro of pancreatic insulin secretion. Endocrinology. 80: 99.

43. Bastenie, P. A. 1969. A physiological approach to the problem of enhanced insulin secretion by intestinal glucose absorption. In International Diabetes Federation, 6th Congress, Stockholm, Sweden, 1967. Diabetes, Proceedings of the 6 th International Congress. J. Östman, editor. Excerpta Medica Foundation, Amsterdam, Holland. 433.

44. Elrick, H., L. Stimmler, C. J. Hlad, Jr., and Y. Arai. 1964. Plasma insulin response to oral and intravenous glucose administration. J. Clin. Endocrinol. 24: 1076.

45. McIntyre, N., C. D. Holdsworth, and D. S. Turner. 1965. Intestinal factors in the control of insulin secretion. J. Clin. Endocrinol. 25: 1317.

46. Cahill, G. F. Jr., and J. S. Soeldner. 1969. Glucose homeostasis: A brief review. Mathematical Biosciences. Supplement I. Hormone Control Systems. 5: 88.

47. Curry, D. L. 1970. Factors affecting insulin secretion in vitro. Amer. J. Clin. Nutr. 23: 305.

48. Sussman, K. E., G. D. Vaughan, and M. R. Stjernholm. 1969. Factors controlling insulin secretion in the perfused isolated rat pancreas. In International Diabetes Federation, 6th Congress, Stockholm, Sweden, 1967. Diabetes, Proceedings of the 6th International Congress. J.
Östman, editor. Excerpta Medica Foundation, Amsterdam, Holland. 123.

49. Creutzfeldt, W., H. Frerichs, and C. Creutzfeldt. 1969. The stimulation and inhibition of insulin secretion in vivo and in vitro. In International Diabetes Federation, 6th Congress, Stockholm, Sweden, 1967. Diabetes, Proceedings of the 6th International Congress. J. Östman, editor. Excerpta Medica Foundation, Amsterdam, Holland. 110.

50. Bressler, R., M. V. Cordon, and K. Brendel. 1969. Studies on the role of adenylcyclase in insulin secretion. Arch. Intern. Med. 123: 248.

51. Park, C. R., J. G. T. Sneyd, J. D. Corbin, L. S. Jefferson, and J. H. Exton. 1969. Role of cyclic adenylate in the actions of insulin. In International Diabetes Federation, 6th Congress, Stockholm, Sweden, 1967. Diabetes, Proceedings of the 6th International Congress. J. Östman, editor. Excerpta Medica Foundation, Amsterdam, Holland. 5.

52. Sols, A. 1965. Regulation of liver glucokinase and muscle hexokinase. In International Diabetes Federation, 5th Congress, Toronto, 1964. On the Nature and Treatment of Diabetes, Proceedings of the 5th International Congress. B. S. Leibel and G. A. Wrenshall, editors. Excerpta Medica Foundation, Amsterdam, Holland. 118.

53. Brolin, S. E., C. Berne, and E. Borglund. 1969. Enzymatic aspects of the stimulation of the B-cells by glucose. In International Diabetes Federation, 6th Congress, Stockholm, Sweden, 1967. Diabetes, Proceedings of the 6th International Congress. J. Östman, editor. Excerpta Medica Foundation, Amsterdam, Holland. 140.

54. Jacobs, G., G. Reichard, E. H. Goodmann, Jr., B. Friedmann, and S. Weinhouse. 1958. Action of insulin and tolbutamide on blood glucose entry and removal. Diabetes. $7: 358$.

55. Reichard, G. A., A. G. Jacobs, P. Kimbel, N. J. Hochella, and S. Weinhouse. 1960. Effects of insulin on blood glucose entry and removal rates in man. Diabetes. 9: 447.

56. Kalant, N., T. R. Csorba, and N. Heller. 1963. Effect of insulin on glucose production and utilization in diabetes. Metabo. Clin. Exp. 12: 1100.

57. Segal, S., M. Berman, and A. Blair. 1961. The metabolism of variously ${ }^{14} \mathrm{C}$-labeled glucose in man and an estimation of the extent of glucose metabolism by the hexose monophosphate pathway. J. Clin. Invest. 40: 1263.

58. Gordon, E. S., and M. Goldberg. 1964. Studies of energy metabolism in human subjects using carbon ${ }^{14}$-labeled compounds. I. Effect of sex, state of nutrition and body weight. Metab. Clin. Exp. 13: 775.

59. Baker, N., W. W. Shreeve, R. A. Shipley, G. E. Incefy, and M. Miller. 1954. "C studies in carbohydrate metabolism. I. The oxidation of glucose in normal human subjects. J. Biol. Chem. 211: 575 .

60. Young, D. R., R. Pelligra, J. Shapira, R. R. Adachi. and K. Skrettingland. 1967. Glucose oxidation and replacement during prolonged exercise in man. J. Appl. Physiol. 23: 734.

61. Manougian, E., M. Pollycove, J. A. Linfoot, and J. H. Lawrence. 1964. ${ }^{14} \mathrm{C}$ glucose kinetic studies in normal, diabetic, and acromegalic subjects. J. Nucl. Med. 5: 763 .

62. Dudrick, S. J., J. M. Long, E. Steiger, and J. E. Rhoads. 1970. Intravenous hyperalimentation. Med. Clin. $N$. Amer. 54: 577.

63. Wilmore, D. W., S. J. Dudrick, H. M. Vars, and J. E. Rhoads. 1968. Long-term intravenous hyperalimentation. Fed. Proc. 27 : 486. 